\title{
E-postadresser til besvær
}

\author{
E-postadresser bør helst være lette å oppfatte, huske og formidle videre.
}

Leger og forskere har behov for å kommunisere med hverandre. E-post har gjort denne kommunikasjonen mye lettere. Med noen få tastetrykk kan man være i forbindelse med kolleger ved andre sykehus og $i$ andre land og utveksle synspunkter, forskningsresultater og manusutkast.

Svært mange institusjoner har en logisk og konsistent måte å lage e-postadresser for sine ansatte på. Noen anvender den første eller de to eller tre første bokstavene i fornavn og etternavn foran @-tegnet. Vanligst er nok likevel å bruke fornavn og etternavn med et punktum mellom. Slik har det vært og er fortsatt ved de fleste norske sykehus og universiteter, for eksempel slik: petter.gjersvik@rikshospitalet.no petter.gjersvik@medisin.uio.no

\section{Nytt sykehus}

Organisatoriske endringer medfører ofte endringer i e-postadressen, noe som kan skape vansker for både avsendere og mottakere av e-post. Da Rikshospitalet, Radiumhospitalet, Ullevål universitetssykehus og Aker universitetssykehus ble slått sammen til Oslo universitetssykehus, fikk alle som jobbet på sykehuset nye e-postadresser. Min ble slik:

petter.gjersvik@

oslo-universitetssykehus.no

Litt lang og tung og vanskelig å formidle til utenlandske kolleger ved korte personlige

Tabell 1 Eksempler på nye e-postadresser for ansatte ved Oslo universitetssykehus

\begin{tabular}{ll} 
Joar Austad & jaustad@ous-hf.no \\
\hline Kristin Bergersen & kbergers@ous-hf.no \\
Kristine Bø & krisbo@ous-hf.no \\
$\begin{array}{l}\text { Daniel de la Rosa } \\
\text { Carrillo }\end{array}$ & dcarrill@ous-hf.no \\
\hline Ragnar Solberg Faye & ragfay@ous-hf.no \\
\hline Kjell Arne Stene Hoff & hofk@ous-hf.no \\
Jan-Øivind Holm & holjan@ous-hf.no \\
Nils-Jørgen Mørk & nmork@ous-hf.no \\
Eli Johanne Nordal & enorda@ous-hf.no \\
Gro Mørk & grmork@ous-hf.no \\
Ingrid Roscher & INROSC@ous-hf.no \\
Astrid Haaskjold Lossius & uxharf@ous-hf.no \\
Caroline Strandhagen & STRMAR@ous-hf.no \\
Elin Holthe Johnsen & elinjohn@ous-hf.no
\end{tabular}

møter på kongresser og $\mathrm{i}$ andre faglige sammenhenger, og vanskelig for dem å skrive korrekt. Etter en tid ble adressen endret til: petter.gjersvik@ous-hf.no

med en nokså unødvendig bindestrek, men $\mathrm{OK}$ - domenenavnet ous.no var allerede opptatt.

Noe senere fikk alle ansatte ved Oslo universitetssykehus for tredje gang på kort tid nye e-postadresser satt opp etter helt nye og helt forskjellige prinsipper. (Samtidig ble alle e-postadresser man hadde sendt e-poster til, slettet fra PC-ens hukommelse.) Selv fikk jeg denne e-postadressen:

sbgpet@ous-hf.no

Hvorfor akkurat bokstavene sbgpet ble valgt, vet jeg ikke. I tabell 1 er angitt de nye e-postadressene til noen kolleger ved min avdeling - til sammen 15 e-postadresser og 15 ulike måter å sette dem opp på.

\section{Begrunnelsen}

Jonette Øyen (med e-postadresse

UXNNJT@ous-hf.no), kommunikasjonsdirektør i staben til administrerende direktør ved sykehuset, er enig $i$ at de nye e-postadressene er ugreie og uforståelige. Hun henviste meg til IT-avdelingen. Sjefen der, Kenneth Solstrand (med e-postadresse Ksolstra@ous-hf.no), sendte saken videre til Morten G. Sevland (med e-postadresse morsev@ous-hf.no).

Sevland skriver i en grundig redegjørelse at en så stor organisasjon som Oslo universitetssykehus, med rundt 26000 ansatte og 35000 e-postkontoer, vil ha svært mange ansatte med like navn. Ved å bruke fornavn og etternavn i e-postadressene vil slike personer måtte få et tall i tillegg, for eksempel Kristine.Olsen@ous-hf.noog Kristine. Olsen2@ous-hf.no. Dette ville trolig ha medført svært mange feilsendinger, særlig til førstnevnte. Å sette inn et mellomnavn - for dem som har et slikt - ville ha medført forskjellige navnestandarder og fare for forveksling og at ansatte uten mellomnavn ville fått mange feilsendinger. Han mener at den mest brukte og ryddigste modellen i store organisasjoner er å bruke e-postadresser som ikke nødvendigvis gjenspeiler brukernes navn. Det vil da ikke være mulig å gjette seg til en brukers e-postadresse. Det viktigste er at e-postadressen ikke er for lang. Faren for søppelpost vil også være mindre.

Mer brukervennlig er det trolig ikke mulig å gjøre det i en så stor organisasjon

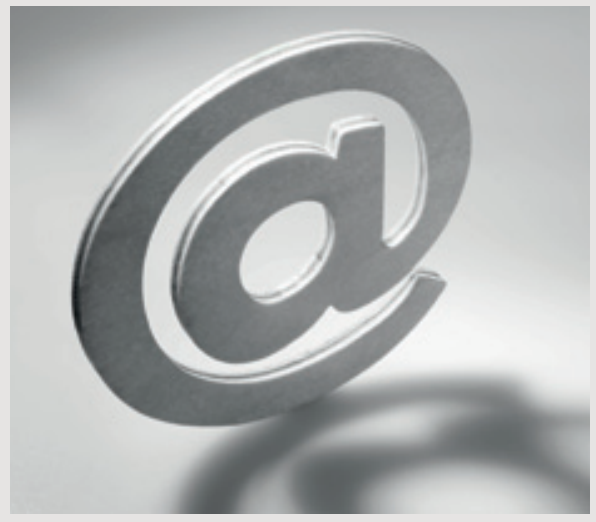

Illustrasjonsfoto Istockphoto

som Oslo universitetssykehus, mener Sevland. Til trøst for dem som var ansatt på sykehuset frem til endringen, vil tidligere e-postadresser med@rikshospitalet.no, @oslo-universitetssykehus.no og@oushf.no fortsatt fungere. Haken er at utgående e-post for mottakerne ser ut som den kommer fra den nye e-postadressen, noe som skaper forvirring. Nyansatte vil ikke ha denne muligheten til å bruke en mer forståelig og intuitiv e-postadresse.

\section{Dårlig språk}

Jeg synes IT-avdelingens begrunnelse for de nye e-postadressene er svak. Brukervennlighet synes ikke å være tillagt særlig vekt. Hos private e-posttilbydere, for eksempel@hotmail.com og@gmail.com, som betjener millioner av e-postadresser, kan man selv velge e-postadresse - forutsatt at adressen ikke er opptatt.

E-postadresser er også språk, kommunikasjon og identitet. Godt språk er å velge gode ord. Krøkkete e-postadresser er dårlig språk.

\section{Petter Gjersvik}

sbgpet@ous-hf.no

Seksjon for hudsykdommer

Oslo universitetssykehus, Rikshospitalet

Petter Gjersvik (f. 1952) er hudlege, dr.med., førsteamanuensis ved Oslo universitetssykehus og medisinsk redaktør i Tidsskriftet. Ingen oppgitte interessekonflikter.

Mottatt 1.7. 2011 og godkjent 6.9. 2011. Medisinsk redaktør Raida Ødegaard. 